\title{
CASE REPORT: MORPHOLOGICAL ASPECTS OF BUERGER'S DISEASE
}

Tsimbalist NS ${ }^{1}$, Suftin BA², Kriuchkova AV ${ }^{1}$, Chupyatova EA¹, Babichenko II

${ }^{1}$ Peoples' Friendship University of Russia, Moscow, Russia

${ }^{2}$ Central Military Clinical Hospital of the National Guard Troops of the Russian Federation, Balashikha, Russia

Buerger's disease is a rather rare pathology characterized by nonatherogenic vascular lesion associated with the inflammation in the intima of the vessel and the thrombus formation. Most often the pathological process affects small and medium caliber arteries. Vascular occlusion can lead to tissue ischemia and the trophic ulcers, and cause the extremity amputation. The disorder pathogenesis has not been fully explored. Literature data indicate that the disease development may be associated with autoimmune processes. The paper presents the results of immunohistochemical study of the material obtained after amputation of the lower extremity in a patient diagnosed with Buerger's disease. The patient had a 15-year tobacco smoking experience. In the inflammatory cell infiltrates around the affected vessels, lymphocytes with CD4, CD8 antigens and IgG immunoglobulin deposits were found, which could be considered as the evidence of the autoimmune mechanisms' involvment. Immunohistochemical reactions with markers of NK cells CD56 and the central component of the C3d complement system were negative. The results of the study suggest that the key role is played by helper and suppressor T lymphocytes, as well as by humoral antibodies of the lgG class.

Keywords: Buerger's disease, immunohistochemistry, CD4, CD8, IgG

Author contribution: Babichenko II, Suftin BA - study concept and design; Suftin BA, Chupyatova EA — data acquisition and processing; Tsimbalist NS, Kriuchkova AV, Babichenko II - manuscript writing; Babichenko II - manuscript editing.

Compliance with ethical standards: the patient signed the informed consent to the study and publishing of the results.

Correspondence should be addressed: Natalia S. Tsimbalist

Kuskovskaya, 1-77, Moscow, 111398; n_zimb@list.ru

Received: 09.12.2019 Accepted: 15.01.2020 Published online: 23.01.2020

DOI: $10.24075 /$ brsmu.2020.004

\section{МОРФОЛОГИЧЕСКАЯ ХАРАКТЕРИСТИКА КЛИНИЧЕСКОГО СЛУЧАЯ БОЛЕЗНИ БЮРГЕРА}

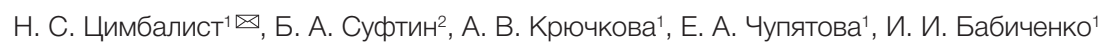

Российский университет дружбы народов, Москва, Россия

2 Главный военный клинический госпиталь войск национальной гвардии Российской Федерации, Балашиха, Россия

\begin{abstract}
Бюлезнь Бюргера - это достаточно редкая патология, для которой характерно неатерогенное поражение сосудов с формированием в интиме сосуда воспалительного процесса и образованием тромба. Наиболее часто в патологический процесс бывают вовлечены артерии мелкого и среднего калибра. Окклюзия сосудов может привести к ишемии тканей, появлению трофических язв и стать причиной ампутации конечности. На сегодняшний день патогенез заболевания остается до конца неизученным. Литературные данные указывают на то, что развитие патологии может быть связано с аутоиммунными процессами. В статье представлены результаты иммуногистохимического исследования материала, полученного после ампутации нижней конечности у пациента с клиническим диагнозом болезнь Бюргера, имевшего 15-летний стаж курения. В воспалительных клеточных инфильтратах вокруг пораженных сосудов были обнаружены лимфоциты с антигенами CD4, CD8 и депозиты иммуноглобулинов lgG, которые могли служить подтверждением участия аутоиммунных механизмов в развитии заболевания. Иммуногистохимические реакции с маркерами NK-клеток CD56 и главного компонента системы комплемента СЗd оказались отрицательными. Полученные результаты позволяют предположить, что основная роль в цепи патогенеза болезни Бюргера принадлежит Т-лимфоцитам-хелперам и супрессорам, а также гуморальным антителам класса IgG.
\end{abstract}

Ключевые слова: болезнь Бюргера, иммуногистохимия, CD4, CD8, IgG

Вклад авторов: И. И. Бабиченко, Б. А. Сустин - концепция и дизайн исследования; Б. А. Сустин, Е. А. Чупятова - сбор и обработка материала; Н. С. Цимбалист, А. В. Крючкова, И. И. Бабиченко - написание текста статьи; И. И. Бабиченко - редактирование.

Соблюдение этических стандартов: пациент подписал добровольное информированное согласие на исследование и публикацию материала.

$\triangle$ Для корреспонденции: Наталья Сергеевна Цимбалист

ул. Кусковская, д. 1, кв. 77, г. Москва, 111398; n_zimb@list.ru

Статья получена: 09.12.2019 Статья принята к печати: 15.01.2020 Опубликована онлайн: 23.01.2020

DOI: 10.24075/vrgmu.2020.004

Buerger's disease is a rare pathology that is most common in Eastern Europe and Asia. [1]. Thromboangiitis obliterans (TAO) was initially described by Felix von Winiwarter in 1879, a more detailed description of the disorder was presented in 1908 by Leo Buerger [2-5]. Thromboangiitis obliterans (Buerger's disease) is a progressive, nonatherosclerotic disease that most often affects small and medium arteries [2]. Blood vessels of various localization may be involved, most often the disease affects the arteries of the limbs, usually the femoral and radial arteries. In rare cases, the coronary, carotid and visceral arteries are affected [6].

According to literary sources, the incidence of the disease in patients with circulatory disorders ranges from $0.5-5 \%$ in
Europe, and in Japan this indicator can reach 16\% [6]. The disorder is more frequently found in male smokers [2, 3, 7]. The typical age of onset is 40-45 [4, 8]. The disease pathogenesis may be associated with endothelial dysfunction [9]. Due to the damaging agents' impact, vascular permeability is impaired, inflammation and thrombosis occur [10]. According to a number of authors, the immune homeostasis failure can lead to the development of the disease.

In patients with Buerger's disease, the released by immune cells inflammatory cytokines level is increased, and the inflammatory reaction exacerbates the severity of the disease $[9,10]$. In TAO patients, the HLA, A28, Ax, B53 and Bx antigens were detected [11]. The TNF $\alpha$, IL1 $\beta$, IL4, IL17 and IL23 
blood plasma level increase was also noted. Elevated levels of IL17 and IL23 indicate the autoimmune processes' development caused by an unknown antigen (possibly a nicotine component) [10]

The clinical manifestations of Buerger's disease include claudication, ulcerations on the toes and ischemic rest pain appear over time [2, 4, 6]. A sensation of coldness and a reduced touch sensitivity of the skin of the feet are noted in the affected extremities [5, 12]. For the diagnosis confirmation, it in necessary to eliminate such conditions as thrombophilia, diabetes, embolism and autoimmune disorders [2, 4].

The cornerstone of the TAO treatment is absolute smoking avoidance [2, 4, 13]. In patients who stop smoking the remission occurs, which reduces the risk of amputation [2]. The patients are also treated with adjuvant medications, such as lloprost, vasodilatators including the prostaglandin analogues, calcium channel antagonists, anticoagulants and antiplatelet drugs including Aspirin [5, 10, 13]. If the patient does not stop smoking tobacco, the disease would progress, which leads to the extremities' amputation [14].

The paper presents the case of an immunohistochemical study of the affected vessels in patient with Buerger's disease (thromboangiitis obliterans) aimed to clarify the inflammatory infiltrate cellular composition and to identify the lgG deposits.

\section{Clinical case report}

Buerger's disease was diagnosed in 36- year old male with 15 -year tobacco smoking experience. The observation period was 6 months. In May 2017, the patient suddenly felt pain in his left foot. He received symptomatic treatment that had no effect. In early June 2017, intensification of pain in the left foot, cold feet, as well as darkening of the toes were noted. The patient was hospitalized, he underwent the left foot Lisfranc amputation because of the left lower leg subacute thrombosis and acute III-degree ischemia. The residual limb (stump) wound did not heal, there were pains in the left foot and lower leg. Swelling of both legs was noted, and flexion contracture of the left knee joint developed. The patient slept in his sitting position. Doppler ultrasonography of the lower extremities' arteries revealed the occlusion of the left anterior tibial artery. Stenosis of the left superficial femoral artery was more than $60 \%$. The dry gangrene of the left lower extremity developed, which led to the amputation amputation at the hip level in August 2017. The clinical diagnosis was TAO with the left anterior tibial artery occlusion, stage IV chronic arterial insufficiency, dry necrosis of the residual limb of the end surface of the left foot soft tissues.

The material was taken from the Central Military Clinical Hospital of the National Guard Troops of the Russian Federation archive. Tissue blocks with tissue fragments taken from the foot and the lower leg were selected for investigation. The sample were subjected to standard processing (tissue sectioning, paraffin blocks preparation, slices' preparation, haematoxylin and eosin staining). The slices were examined using the Axioplan 2 Imaging microscope (Karl Zeiss; Germany), the pictures were taken using the AxioCam ERc5s camera (Karl Zeiss; Germany).

To study the inflammatory infiltrate cellular composition and detect lgG deposits, an immunohistochemical study was performed using the Quanto protocol. The UltraVision Quanto system (Thermo Fisher Scientific; USA) reagents were used including the horseradish peroxidase (HRP) polymer conjugate. The study was carried out using the Autosteiner 360 unit (Thermo Fisher Scientific; UK). The following sera were used as antibodies: mouse monoclonal antibody against CD8 (Cell Marque; USA), rabbit monoclonal antibody against CD4 (Cell Marque; USA), rabbit polyclonal antibody against IgG (Cell Marque; USA), rabbit monoclonal antibody against CD56 (Epitomics; USA), rabbit monoclonal antibody against C3d (Clone SP7, Thermo Fisher Scientific; UK). The exposure time of antibody on each slice was 20 minutes.

A macroscopic examination of the left lower extremity resected at the level of the middle and lower third of the thigh revealed the foot absence along the metatarsal-tarsal joints (after the Lisfranc amputation) with the unhealed wound and the blue-gray surrounding tissues. The obstructing thrombi of arteries and veins at the level of the popliteal artery were also found detecte. The lower leg muscles were red-yellow and pale.The muscles at the resection level were reddish.

The tissue samples contained the vessels from the left hip, lower leg and foot. Samples were taken in the immediate vicinity of the lesions of gangrene. During a histological examination, necrosis was detected in the foot and lower leg. Mixed thrombi of arteries and veins of the foot and lower leg were revealed, sometimes with recanalization and organization, partial obliteration of the lumen was also noted. Fig. 1 shows a cross section of the foot artery, there are intra-parietal and perivascular fibrosis, necrosis of the vessel wall. Microphotography (Fig. 2) demonstrates the cross section of the lower leg artery with the organized thrombus and recanalization. No thrombotic masses were found in the femoral vessels, however, a partial obliteration of their lumen was noted. There were no atherosclerotic plaques. Mixed thrombi, necrosis of the vessel wall and partial obliteration of the lumen were revealed in the different caliber vessels. In the large vessels, a considerable amount of vasa vasorum was detected, as well as lymphocytes in the wall, due to which the patient was diagnosed with TAO.

The material was subjected to immunohistochemical study. Further microscopy showed that in the vessels of small and medium caliber, mainly in arterioles, positive cytoplasmic reactions took place when using the antibody against the receptor of the T-lymphocytes CD4 subpopulations' marker (mainly in the wall of the lower leg artery (Fig. 3)) and the T-lymphocytes CD8 subpopulations' marker (in the wall of the vessel (arteriole) of the foot (Fig. 4)). IgG deposits were observed on the surface of vascular endothelium and in the vessel walls (Fig. 5). A negative reaction was detected for the antibodies against the CD56 receptor, NK cells markers, as well as against the cental component of the C3d complement system.

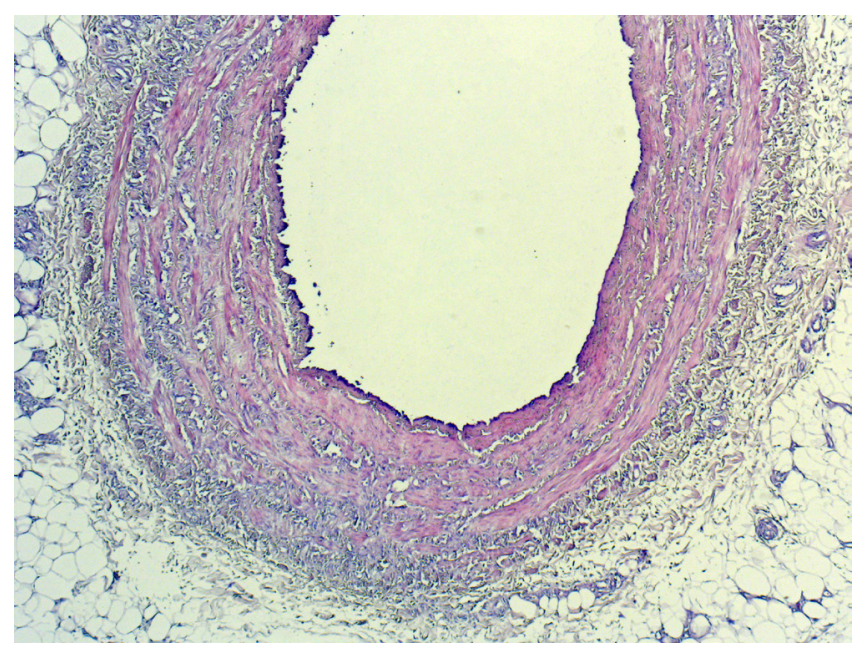

Fig. 1. Foot artery cross section. Intra-parietal and perivascular fibrosis. Microphotograph. Hematoxylin and eosin stain (x50) 


\section{Clinical case discussion}

In patients with Buerger's disease, the pathological process begins in distally located vessels, progressing to proximally located vessels [2]. The main pathological changes are the formation of thrombi, intra-parietal and perivascular fibrosis of blood vessels [5]. Three phases of the disease are distinguished: acute, subacute and chronic [2, 3]. In the acute phase, the onset of inflammation is noted, associated with neutrophil infiltration and thrombotic vascular occlusion. The vessel walls are relatively intact. In the subacute phase, a thrombus organization occurs with continuing platelet adherence. In the chronic phase, in the absence of inflammatory mediators, blood vessel fibrosis is observed with its blockage by an organized thrombus. Later recanalization may occur [2]. In case of severe pathological changes and ulcers, amputation of the extremity is performed [5, 10]. For treatment the endovascular intervention is used, operations are performed that involve shunting, resection of the posterior tibial veins [13].

In the studied clinical case, the patient's extremity was amputated becase of the left leg gangrene. A histological examination of the vessels revealed mixed thrombi, organization phenomena and partial obliteration of the lumen.

When diagnosed, Buerger's disease must be distinguished from other diseases associated with vascular lesion. Thus, in patients with TAO, the vascular lesion is characterized by inflammatory cell infiltration of all three layers of the artery wall. In patients with atherosclerosis, only intima is involved in the pathological process [2]. Migratory thrombophlebitis allows to distinguish Buerger's disease from other types of angiitis. The main histological signs of the disease are the intimal hyperplasia such as capillary angiomatosis, vessels clogged with thrombotic masses, lack of calcification of the vessel middle coat and panflebitis of the veins [13].

The results of our study confirm that the main pathological changes in patients with Buerger's disease are arterial thrombosis with inflammatory infiltration in all three layers of the wall with intimal hyperplasia in the absence of atherosclerosis signs. According to a number of authors [3], the onset and maintenance of the inflammatory response depends on the endothelium integrity. Endothelial dysfunction leads to the endothelium-dependent vasorelaxation impairment. In our study, IgG deposits were found on the surface of the endothelium and in the vessel wall.

An increase in the level of proinflammatory cytokines IL1 $1 \beta$, TNF $\alpha$ and IL6 in the Buerger's disease patients' plasma was demonstrated by [10], as well as the increase of the level of Th1 cytokines (IFN $\gamma$ and IL12). For Th2 cytokines, the increase in IL4, IL5 and IL13, together with the decrease in IL10 was noted, as well as an increase in cytokine profiles Th17 (IL17 and IL23), indicating the involvement of autoimmune mechanisms. Some authors [2] suggested that patients Buerger's disease couls have specific cellular immunity against arterial antigens, specific humoral antiarterial antibodies, immune complexes.

The paper [15] demonstrates the results of tissue samples obtained from the artery dorsalis pedis immunohistochemical study aimed to detect the new antigens which could be responsible for local inflammatory reactions and structural changes in patients with TAO. Antigens such as CD34, CD44 and CD90 have been identified. Researchers suggest that the receptor/ligand pair CD90/CD11c plays an important role in attracting mononuclear cells to the site of damage.

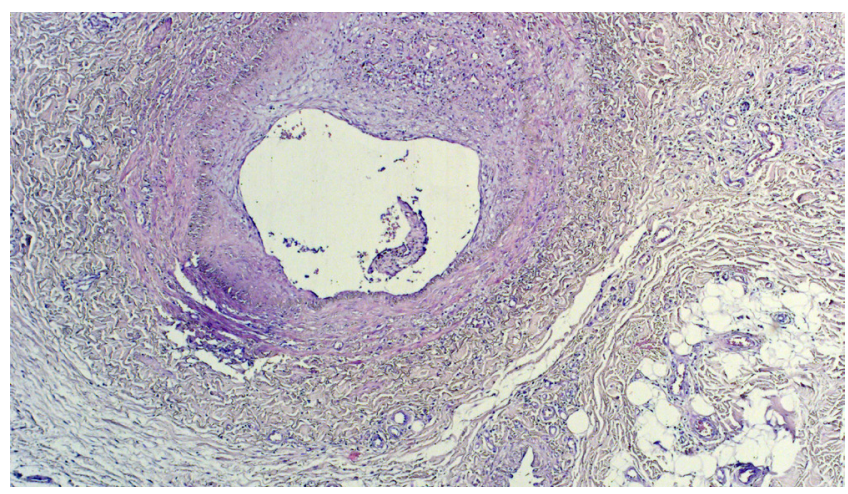

Fig. 2. Lower leg artery cross section. Organized thrombus with recanalization Microphotograph. Hematoxylin and eosin stain (x50)

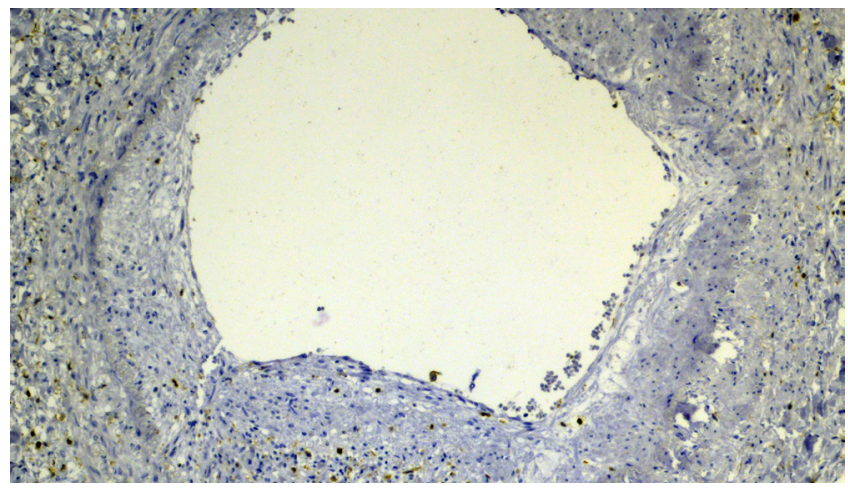

Fig. 3. Lower leg artery. Immunohistochemical reaction with antibodies against CD4 protein: cytoplasmic marker localization. Microphotograph. DAB and hematoxylin stain (x100)

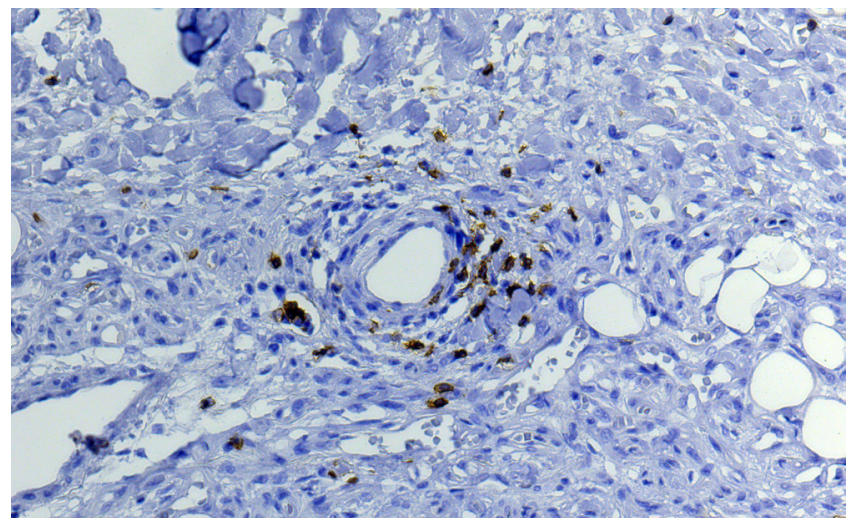

Fig. 4. Foot arteriole. Immunohistochemical reaction with antibodies against CD8 protein: cytoplasmic marker localization. Microphotograph. DAB and hematoxylin stain (x200)

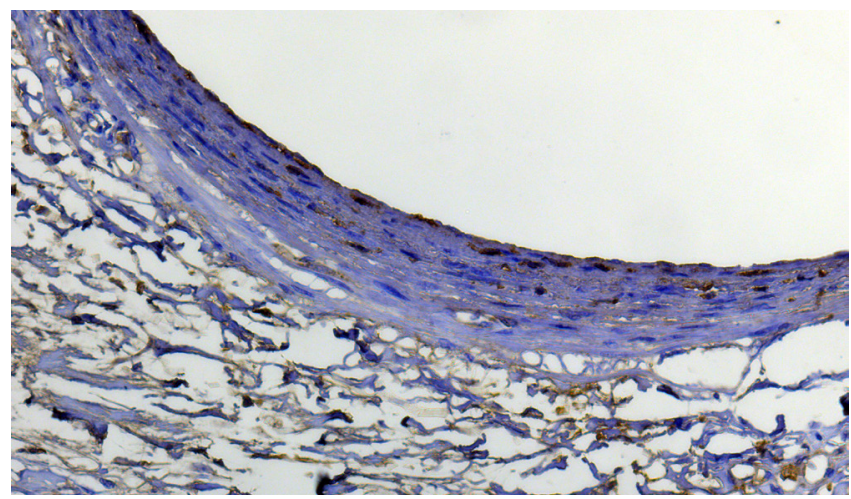

Fig. 5. Foot artery. Immunohistochemical reaction with antibodies against IgG protein: endothelial marker localization. Microphotograph. DAB and hematoxylin stain (x200) 
In our study the tissue samples were taken from the amputated extremity (foot, leg and hip) of the patient with diagnosed Buerger's disease, having a 15-year tobacco smoking experience. The cells were identified containing markers which could indicate the involvement of the immunity in the pathogenesis of the disease (CD4, CD8, IgG deposits).

\section{CONCLUSION}

The results of the study suggest that autoimmune mechanisms are involved in the development of the disease, with the key role played by helper and suppressor $\mathrm{T}$ lymphocytes, as well as humoral immunity due to lgG.

\section{References}

1. Shionoya S, Leu HJ, Lie JT. Buerger's disease (thromboangiitis obliterans). In: Stehbens WE, Lie JT, eds. Vascular pathology. London: Chapman \& Hall Medical, 1995; p. 657-78.

2. Qaja E, Fortune MA. Buerger Disease (Thromboangiitis Obliterans). StatPearls [Internet]. 2019 Nov [cited 2019 Nov 11]; [about 3 p.] Available from: https://www.statpearls.com/sp/rn/18685/.

3. Rivera-Chavarría IJ, Brenes-Gutiérrez JD. Thromboangiitis obliterans (Buerger's disease). Ann Med Surg (Lond). 2016; (7): 79-82. PubMed PMID: 27144003.

4. Seebald J, Gritters L. Thromboangiitis obliterans (Buerger disease). Radiol Case Rep. 2015; 10 (3): 9-11. PubMed PMID: 26649109.

5. Li Q-L, He D-H, Huang Y-H, Niu M. Thromboangiitis obliterans in two brothers. Experimental and Therapeutic Medicine. 2013; 6 (2): 317-20. PubMed PMID: 24137181.

6. Nobre CA, Vieira WP, da Rocha FE, de Carvalho JF, Rodrigues CE. Clinical, arteriographic and histopathologic analysis of 13 patients with thromboangiitis obliterans and coronary involvement. Isr Med Assoc J. 2014; 16 (7): 449-53. PubMed PMID: 25167694.

7. Shilkina NP, Lileeva MA, Drjazhenkova IV, Kaufman EV Prokopenko AV. Obliterirujushhij trombangiit i ateroskleroz sosudov nizhnih konechnostej: kliniko-morfologicheskaja harakteristika. Klinicheskaja gerontologija. 2006; 12 (2): 15-18.

8. Elfarra M, Rădulescu D, Peride I, Niculae A, Ciocâlteu A, Checheriţă IA, et. al. Thromboangiitis obliterans - case report. Chirurgia (Bucur). 2015; 110 (2): 183-7. PubMed PMID: 26011844.

9. Igari K, Kudo T, Toyofuku T, Inoue Y. Endothelial dysfunction in patients with Buerger disease. Vasc Health Risk Manag. 2017; (13): 317-23. PubMed PMID: 28860792.

10. Dellalibera-Joviliano R, Joviliano EE, Silva JS, Evora PR. Activation of cytokines corroborate with development of inflammation and autoimmunity in thromboangiitis obliterans patients. Clin Exp Immunol. 2012; 170 (1): 28-35. PubMed PMID: 22943198.

11. Schmitt J, Schmidt C, Alan C, Haller C, Perrier P. Population genetics, immunologic evaluation and Buerger's disease. Projection through a personal study comprising 127 cases of juvenile arteriopathy. Bull Acad Natl Med. 1993; 177 (7): 1153-64. PubMed PMID: 8149255

12. Wan J, Yang Y, Ma ZH, Sun Y, Liu YQ, Li GJ, et al. Autologous peripheral blood stem cell transplantation to treat thromboangiitis obliterans: preliminary results. Eur Rev Med Pharmacol Sci. 2016; 20 (3): 509-13. PubMed PMID: 26914127

13. Zerbino DD, Zimba EA, Bagrij NN. Obliterirujushhij trombangiit (bolezn' Bjurgera): sovremennoe sostojanie problemy. Angiologija i sosudistaja hirurgija. 2016; 22 (4): 185-92.

14. Sinclair NR, Laub DR. Thromboangiitis Obliterans (Buerger's Disease). Eplasty [Internet]. 2015 [cited 2015 Apr 10]; [about 6 p.]. Available from: http://www.eplasty.com/interesting-cases/3591thromboangiitis-obliterans-(buerger's-disease)

15. Guzel E, Topal E, Yildirim A, Atilla P, Akkus M, Dagdeviren A. Targeting novel antigens in the arterial wall in thromboangiitis obliterans. Folia Histochem Cytobiol. 2010; 48 (1): 134-41. PubMed PMID: 20529829.

\section{Литература}

1. Shionoya S, Leu HJ, Lie JT. Buerger's disease (thromboangiitis obliterans). In: Stehbens WE, Lie JT, eds. Vascular pathology. London: Chapman \& Hall Medical, 1995; p. 657-78.

2. Qaja E, Fortune MA. Buerger Disease (Thromboangiitis Obliterans) StatPearls [Internet]. 2019 Nov [cited 2019 Nov 11]; [about 3 p.]. Available from: https://www.statpearls.com/sp/rn/18685/.

3. Rivera-Chavarría IJ, Brenes-Gutiérrez JD. Thromboangiitis obliterans (Buerger's disease). Ann Med Surg (Lond). 2016; (7): 79-82. PubMed PMID: 27144003.

4. Seebald J, Gritters L. Thromboangiitis obliterans (Buerger disease). Radiol Case Rep. 2015; 10 (3): 9-11. PubMed PMID: 26649109.

5. Li Q-L, He D-H, Huang Y-H, Niu M. Thromboangiitis obliterans in two brothers. Experimental and Therapeutic Medicine. 2013; 6 (2): 317-20. PubMed PMID: 24137181.

6. Nobre CA, Vieira WP, da Rocha FE, de Carvalho JF, Rodrigues CE. Clinical, arteriographic and histopathologic analysis of 13 patients with thromboangiitis obliterans and coronary involvement. Isr Med Assoc J. 2014; 16 (7): 449-53. PubMed PMID: 25167694.

7. Шилкина Н. П., Лилеева М. А., Дряженкова И. В., Кауфман Е. В. Прокопенко А. В. Облитерирующий тромбангиит и атеросклероз сосудов нижних конечностей: клинико-морфологическая характеристика. Клиническая геронтология. 2006; 12 (2): 15-18.

8. Elfarra M, Rădulescu D, Peride I, Niculae A, Ciocâlteu A, Checheriță IA, et. al. Thromboangiitis obliterans - case report. Chirurgia (Bucur). 2015; 110 (2): 183-7. PubMed PMID: 26011844

9. Igari K, Kudo T, Toyofuku T, Inoue Y. Endothelial dysfunction in

patients with Buerger disease. Vasc Health Risk Manag. 2017; (13): 317-23. PubMed PMID: 28860792

10. Dellalibera-Joviliano R, Joviliano EE, Silva JS, Evora PR. Activation of cytokines corroborate with development of inflammation and autoimmunity in thromboangiitis obliterans patients. Clin Exp Immunol. 2012; 170 (1): 28-35. PubMed PMID: 22943198

11. Schmitt J, Schmidt C, Alan C, Haller C, Perrier P. Population genetics, immunologic evaluation and Buerger's disease. Projection through a personal study comprising 127 cases of juvenile arteriopathy. Bull Acad Natl Med. 1993; 177 (7): 1153-64. PubMed PMID: 8149255

12. Wan J, Yang Y, Ma ZH, Sun Y, Liu YQ, Li GJ, et al. Autologous peripheral blood stem cell transplantation to treat thromboangiitis obliterans: preliminary results. Eur Rev Med Pharmacol Sci. 2016; 20 (3): 509-13. PubMed PMID: 26914127

13. Зербино Д. Д., Зимба Е. А., Багрий Н. Н. Облитерирующий тромбангиит (болезнь Бюргера): современное состояние проблемы. Ангиология и сосудистая хирургия. 2016; 22 (4): 185-92.

14. Sinclair NR, Laub DR. Thromboangiitis Obliterans (Buerger's Disease). Eplasty [Internet]. 2015 [cited 2015 Apr 10]; [about 6 p.]. Available from: http://www.eplasty.com/interesting-cases/3591thromboangiitis-obliterans-(buerger's-disease)

15. Guzel E, Topal E, Yildirim A, Atilla P, Akkus M, Dagdeviren A. Targeting novel antigens in the arterial wall in thromboangiitis obliterans. Folia Histochem Cytobiol. 2010; 48 (1): 134-41. PubMed PMID: 20529829. 